\title{
Design of a one-tube hemi-nested PCR for detection of Toxoplasma gondii and comparison of three DNA purification methods
}

\author{
MARC PUJOL-RIQUÉ, FRANCIS DEROUIN*, ALBERTO GARCÍA-QUINTANILLA, M. E. VALLS, \\ J. M. MIRÓ† and M. T. JIMÉNEZ DE ANTA
}

Servei de Microbiologia and $\uparrow$ Servei de Malalties Infeccioses, IDIBAPS, Hospital Clínic Universitari de Barcelona. Facultat de Medicina, Universitat de Barcelona, Spain and * Laboratoire de Parasitologie-Mycologie, Hôpital Saint-Louis, Paris, France

\begin{abstract}
The aims of the present study were to design an easy and sensitive DNA amplification method for detection of Toxoplasma gondii with low risk of accidental contamination, and to find a rapid method for purification of clinical samples containing potential inhibitors of the amplification reaction. With a pair of primers amplifying a 619-bp fragment of the B1 gene of this parasite it was possible to detect DNA equivalent to 10 parasites. When a third primer was added to the same tube, sensitivity increased to 0.1 parasite. In a comparison of different DNA purification methods, the High Pure PCR Template Preparation Kit (Boehringer Mannheim, Germany) gave the best results. With this purification method and the one-tube hemi-nested PCR, $T$. gondii DNA was detected in $14(87.5 \%)$ of 16 clinical specimens (amniotic fluid, broncho-alveolar lavage, bone marrow, blood, liver biopsy) in which the parasite was demonstrated by cell culture.
\end{abstract}

\section{Introduction}

Toxoplasma gondii is the aetiological agent of toxoplasmosis, a disease generally asymptomatic in healthy adults. However, primary infection acquired during pregnancy may result in fatal or severe infection of the fetus [1]. In immunocompromised patients, and especially in those with AIDS, toxoplasmic encephalitis or extracerebral toxoplasmosis may occur, usually resulting from reactivation of chronic infection, with an incidence of up to $50 \%$ in HIV-infected patients not receiving specific anti-toxoplasma prophylaxis [2]. Reactivating toxoplasmosis can also cause severe damage in organ and bone marrow transplant recipients [3] and in those with immunodepressive neoplasms [4]. In organ transplant recipients, there is an additional risk of transmission of $T$. gondii from a seropositive donor to a seronegative recipient [5].

T. gondii infections in immunocompromised patients are often rapidly progressive and associated with

Received 16 July 1998; revised version accepted 15 Dec. 1998.

Corresponding author: Dr M. Pujol (e-mail: pujol@medicina. ub.es). significant morbidity and mortality [6]. Serological tests fail to give unequivocal diagnosis in patients with affected immunity [7]. Presently, the diagnosis of toxoplasmosis in these patients is usually suspected on clinical or radiological data, with definite diagnosis being obtained within 2-3 weeks by the regression of the lesions after specific treatment $[8,9]$. Isolation of the parasite from several clinical specimens can be achieved, but most isolation techniques (mouse inoculation, tissue culture) require several days or weeks before results can be obtained.

In an attempt to reduce this delay, PCR techniques have been applied to the diagnosis of toxoplasmosis. PCR analysis of amniotic fluid has proved to be the most useful diagnostic method for congenital toxoplasmosis [10] and it is also useful in adult immunocompromised patients, particularly in those with extracerebral disease [11]. However, the most sensitive methods, nested PCR or hybridisation after amplification, are time-consuming or susceptible to accidental cross-contamination of DNA, and a rapid and optimal method for purification of the DNA of the large numbers of clinical specimens available for PCR is lacking. Therefore, this study attempted to optimise the conditions for a rapid and sensitive PCR analysis of clinical material from different origins. 


\section{Materials and methods}

\section{Parasite samples}

T. gondii tachyzoites of the RH strain were obtained from Swiss albino mice ascites 2 days after intraperitoneal injection of the parasite.

To test the sensitivity of the amplification methods, serial dilutions of parasite DNA were prepared from purified tachyzoites. Parasites collected from ascites were washed and resuspended in PBS at a concentration of $10^{5} / \mathrm{ml}$. DNA was released from the parasites by proteinase $\mathrm{K}$ (Boehringer Mannheim, Germany) digestion $(300 \mu \mathrm{g} / \mathrm{ml})$ for $1 \mathrm{~h}$ at $55^{\circ} \mathrm{C}$. After inactivating the proteinase $\mathrm{K}$ at $95^{\circ} \mathrm{C}$ for $10 \mathrm{~min}$, five 10 -fold serial dilutions in PBS were prepared.

To compare the efficiency of different purification methods, suspensions of tachyzoites at $10^{3}$ or $10^{4}$ parasites $/ \mathrm{ml}$ were prepared in PBS or in a suspension of human blood leucocytes obtained from $4 \mathrm{ml}$ of EDTA blood from a $T$. gondii seronegative donor. Leucocytes were separated from erythrocytes by a lysis and centrifugation method [12]. Briefly, an EDTA blood sample was diluted 1 in 4 with lysis buffer (10 mM KHCO3, $155 \mathrm{mM} \mathrm{NH4Cl),} \mathrm{incubated} \mathrm{for}$ $30 \mathrm{~min}$, centrifuged at $400 \mathrm{~g}$ for $10 \mathrm{~min}$, and the cell pellet was lysed and centrifuged again with $10 \mathrm{ml}$ of lysis buffer. For each parasite suspension, DNA was released from parasites by means of proteinase $\mathrm{K}$ digestion $(300 \mu \mathrm{g} / \mathrm{ml})$ for $1 \mathrm{~h}$ at $55^{\circ} \mathrm{C}$. Each sample was then divided into three aliquots and submitted to three different DNA purification methods, as described below.

In the first method, proteinase $\mathrm{K}$ was inactivated at $95^{\circ} \mathrm{C}$ for $10 \mathrm{~min}$, then nucleic acids were purified by a procedure modified from Loparev et al. [13]. Briefly, the resulting crude cell lysate was centrifuged for $10 \mathrm{~min}$ at $13000 \mathrm{rpm}$ with one volume of chloroform: isoamyl alcohol (24:1). The aqueous phase was removed, mixed with one volume of isopropanol and centrifuged for $30 \mathrm{~min}$ at $13000 \mathrm{rpm}$. The resulting pellet was centrifuged for $10 \mathrm{~min}$ at $13000 \mathrm{rpm}$ in $800 \mu \mathrm{l}$ of ethanol $70 \%$. The dried pellet was resuspended with $100 \mu \mathrm{l}$ of TE buffer (10 mM Tris, $1 \mathrm{mM}$ EDTA, pH 8).

Two other purification methods based on column filtration were used - the silica membrane columns from the High Pure PCR Template Preparation Kit (Boehringer Mannheim) and the Nucleospin $\mathrm{C}+\mathrm{T}$ kit (Macherey-Nagel, Germany). With both kits, DNA was purified according to the manufacturer's instructions.

\section{Selection of primers}

Primers derived from the B1 gene of $T$. gondii were chosen because it appears to be conserved in different parasite strains and is present in 25-50 copies in the genome [14]. Two different primers flanking a 619-bp fragment (TM1 and TM2) were designed. For the hemi-nested PCR, an internal primer (TM3) giving a 362-bp fragment was designed, taking possible incompatibilities with the latter two into account (Table 1). The theoretical specificity of these primers was determined from the GenBank database.

\section{Processing samples by single-step PCR}

Samples $(10 \mu \mathrm{l})$ of specimen preparations were added to a final volume of $50 \mu \mathrm{l}$ of PCR buffer consisting of $50 \mathrm{mM} \mathrm{KCl}, 10 \mathrm{mM}$ Tris- $\mathrm{HCl}$ (pH 8.3), $2.5 \mathrm{mM} \mathrm{MgCl} 2$, $200 \mu \mathrm{M}$ each of dATP, dCTP, dGTP and $400 \mu \mathrm{M}$ dUTP, primers TM1 and TM2 at $0.5 \mu \mathrm{M}$, and $1 \mathrm{U}$ of TaqDNA polymerase (Boehringer Mannheim). To minimise the risks of contamination, $0.5 \mathrm{U}$ of uracil-DNA-glycosylase (Boehringer Mannheim) was added. Samples were overlaid with mineral oil and amplified in a thermocycler (MJ Research, MA, USA) for 40 cycles. After an initial denaturation for $3 \mathrm{~min}$ at $95^{\circ} \mathrm{C}$, the conditions for each cycle were: denaturation at $94^{\circ} \mathrm{C}$ for $30 \mathrm{~s}$, annealing at $60^{\circ} \mathrm{C}$ for $30 \mathrm{~s}$ and elongation at $72^{\circ} \mathrm{C}$ for $1 \mathrm{~min}$; the final extension step was continued for a further $10 \mathrm{~min}$. A negative control (de-ionised water) was included. PCR products were visualised on an agarose $2 \%$ gel stained with ethidium bromide and compared to a 100-bp DNA ladder (Life Tech, Gibco BRL, MD, USA).

\section{Processing samples by one-tube hemi-nested PCR}

Specimen preparation $(10 \mu \mathrm{l})$ was added to a final volume of $50 \mu \mathrm{l}$ of PCR buffer consisting of $50 \mathrm{mM}$ $\mathrm{KCl}, 10 \mathrm{mM}$ Tris- $\mathrm{HCl}$ (pH 8.3), $1.5 \mathrm{mM} \mathrm{MgCl2}$, $200 \mu \mathrm{M}$ each of dATP, dCTP, dGTP and $400 \mu \mathrm{M}$ dUTP, primer TM1 at $0.01 \mu \mathrm{M}$, primer TM2 at $0.1 \mu \mathrm{M}$ and primer TM3 at $1 \mu \mathrm{M}$, and $2 \mathrm{U}$ of TaqDNA polymerase. To minimise the risks of contamination, $0.5 \mathrm{U}$ of uracil-DNA-glycosylase was added. Samples were overlaid with mineral oil and amplified in a thermocycler for two rounds of 30 cycles each. After an initial denaturation for $3 \mathrm{~min}$ at $95^{\circ} \mathrm{C}$, conditions for each cycle in the first round were: denaturation at $94^{\circ} \mathrm{C}$ for $30 \mathrm{~s}$, annealing at $65^{\circ} \mathrm{C}$ for $30 \mathrm{~s}$ and elongation at $72^{\circ} \mathrm{C}$ for $1 \mathrm{~min}$. After an additional extension for $10 \mathrm{~min}$, the second round was performed in the same way as the first, but with an annealing step at $55^{\circ} \mathrm{C}$. A negative control (de-ionised water) was included in each experiment. A positive control (RH tachyzoites) was

Table 1. Primers used in the different amplification methods

\begin{tabular}{llc}
\hline Primer & Sequence & $\begin{array}{c}\text { PCR } \\
\text { product }\end{array}$ \\
\hline TM1 & 5'-GAGAGGTCCGCCCCCACAAG & $\ldots$ \\
TM2 & 5'-CTGCTGGTGCGACGGGAGTG & $619 \mathrm{bp}^{*}$ \\
TM3 & 5'-CAGGAGTTGGATTTTGTAGA & $362 \mathrm{bp}^{\dagger}$ \\
\hline
\end{tabular}

*With TM1 and TM2.

${ }^{\dagger}$ With TM1, TM2 and TM3. 
also included when testing patient samples. PCR products were visualised as described above.

\section{Detection of $T$. gondii in human specimens}

To assess the specificity of the hemi-nested PCR, 10 EDTA blood samples treated by the lysis-centrifugation method described above from patients serologically negative for $T$. gondii were tested. Also, stored clinical samples $\left(-80^{\circ} \mathrm{C}\right)$ from 16 patients in whom $T$. gondii infection had been proved by MRC5 tissue culture [15] were analysed (Table 2). The High Pure PCR Template Preparation Kit was used for DNA purification. A synthetic DNA fragment of $934 \mathrm{bp}$ obtained from the gene encoding the verotoxin-1 of Escherichia coli was added to each sample in parallel as a control for the presence of inhibitors.

\section{Results}

\section{Sensitivity of the amplification methods}

The respective sensitivity of single PCR was estimated from the test with serial dilutions of purified parasitic DNA. With the single-step PCR it was possible to detect DNA extracted from $10 \mathrm{RH}$ tachyzoites, whereas the one-tube hemi-nested PCR method was still positive at a dilution of DNA corresponding to 0.1 parasites (Fig. 1).

\section{Comparison of purification methods}

The efficiency of the three DNA purification methods was examined in PBS and leucocyte samples spiked with purified tachyzoites. Each amplification sample contained 10 and 100 parasites in PBS, and 100

Table 2. Hemi-nested PCR of positive samples by cell culture

\begin{tabular}{lllll}
\hline Sample no. & Type of sample & Date of collection & Clinical condition & $\begin{array}{c}\text { Result } \\
\text { of PCR }\end{array}$ \\
\hline 1 & Amniotic fluid & Nov. 1991 & Pregnancy* & + \\
2 & Amniotic fluid & July 1993 & Pregnancy & + \\
3 & Amniotic fluid & Oct. 1993 & Pregnancy & + \\
4 & Amniotic fluid & April 1996 & Pregnancy & + \\
5 & Amniotic fluid & April 1997 & Pregnancy & + \\
6 & Blood & April 1993 & HIV infection & + \\
7 & Blood & Aug. 1996 & HIV infection & + \\
8 & Liver biopsy & Aug. 1992 & HIV infection & + \\
9 & BAL & Feb. 1996 & Immunosuppression & + \\
10 & BAL & Aug. 1992 & HIV infection & + \\
11 & BAL & Feb. 1993 & HIV infection & + \\
12 & BAL & Jan. 1993 & HIV infection & + \\
13 & BAL & April 1993 & HIV infection & - \\
14 & Bone marrow & Oct. 1991 & HIV infection & + \\
15 & Bone marrow & June 1992 & BM transplantation & + \\
16 & Bone marrow & Dec. 1993 & HIV infection & - \\
\hline BAL & & & & \\
\hline
\end{tabular}

BAL, broncho-alveolar lavage; BM, bone marrow.

${ }^{*}$ All pregnant patients seroconverted to $T$. gondii during the pregnancy.

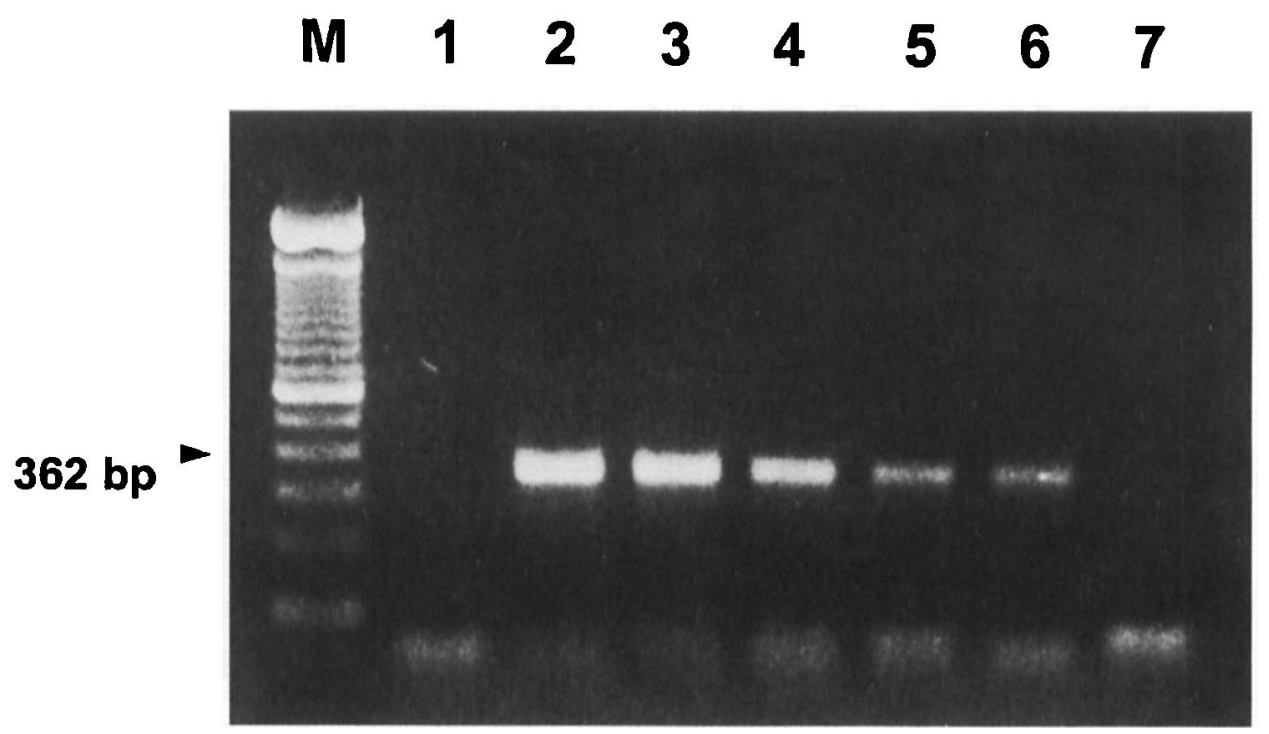

Fig. 1. Gel electrophoresis of amplification products after one-tube hemi-nested PCR (primers TM1, TM2 and TM3) for RH strain of $T$. gondii. Lane M, mol.-wt marker; 1, negative control (de-ionised water); 2, DNA from 1000 parasites; 3, DNA from 100 parasites; 4, DNA from 10 parasites; 5, DNA from one parasite; 6, DNA from 0.1 parasite; 7, DNA from 0.01 parasite. 
parasites in leucocyte suspension, respectively. After lysis with proteinase $\mathrm{K}$, an aliquot of each sample was submitted to each DNA purification method. A positive signal was obtained in the three methods after one-tube hemi-nested PCR and electrophoresis on an agarose 2\% gel stained with ethidium bromide. However, the signals were more intense with the High Pure PCR Template Preparation Kit, particularly in samples containing 10 parasites in PBS (Fig. 2).

In view of these results, it was concluded that the DNA from patient samples should be purified with the High Pure PCR Preparation Kit and amplified with the onetube hemi-nested PCR method.

\section{Processing of clinical specimens}

The PCR analysis of EDTA blood from patients without anti-toxoplasma antibodies was negative. Fourteen $(87.5 \%)$ of the 16 stored clinical samples in which $T$. gondii had been demonstrated by tissue culture were PCR positive (Fig. 3). Two patients had negative PCR, with no PCR inhibitors identified.

\section{Discussion}

PCR has been shown to have good potential as a diagnostic tool for detection of toxoplasmosis in immunodepressed patients. Nested PCR assays [16] or the use of a hybridisation assay after amplification are more sensitive than single-step PCR [11]. However, these methods are time-consuming and, in the case of the two-tube nested PCR, accidental cross-contamination of the sample may occur. In contrast, the one-tube hemi-nested PCR is performed inside a single tube and uracil-DNA-glycosylase can be used to eliminate possible carry-over contamination of PCR products of other positive samples. The one-tube hemi-nested PCR described above detected DNA equivalent to $0.1 \mathrm{RH}$ tachyzoites $(10 / \mathrm{ml})$ and is at least 100 -fold more sensitive than the single-step PCR. After proteinase K digestion and with single-step PCR to amplify the B1 gene followed by hybridisation, Khalifa et al. [11] were able to detect one parasite genome in $10 \mu \mathrm{l}$ of crude DNA sample $(100 / \mathrm{ml})$ in the absence of concomitant negative human DNA. Following heat denaturation of parasites, Novati et al. [17] detected 100-500 parasite genomes $/ \mathrm{ml}$ in PBS by using a two-tube nested PCR to amplify the $\mathrm{B} 1$ gene.

Before amplification, samples must be appropriately prepared to eliminate inhibitors of the TaqDNA polymerase. Detection of $T$. gondii DNA is possible by boiling cerebrospinal fluid before the assay [17]. Other human samples can contain inhibitors [18]. Specimens containing potential inhibitors that were prepared with proteinase $\mathrm{K}$ digestion before PCR yielded good results $[11,19]$. However, the use of proteinase $\mathrm{K}$ alone may be insufficient for preparing the clinical samples and some groups prefer to treat them after a purification step with organic diluents or DNA affinity-based methods [16, 20, 21]. These methods allow DNA concentration and, therefore, increase diagnostic sensitivity. Methods based on the use of affinity DNA purification avoid the use of toxic substances. Moreover, these methods are faster than conventional ones, because DNA can be isolated in minutes. With the High Pure PCR Template Preparation Kit, 14 of 16 samples proved to contain $T$. gondii by cell culture were PCR positive. Some of these specimens, such as blood or bone marrow, might contain inhibitors of the amplification reaction even after phenol extraction [18]. No inhibitor was detected in any sample. In one of the two patients with negative PCR, the tissue culture showed very few parasites. The discrepancy between culture and PCR might also be explained by the storage conditions, as the samples

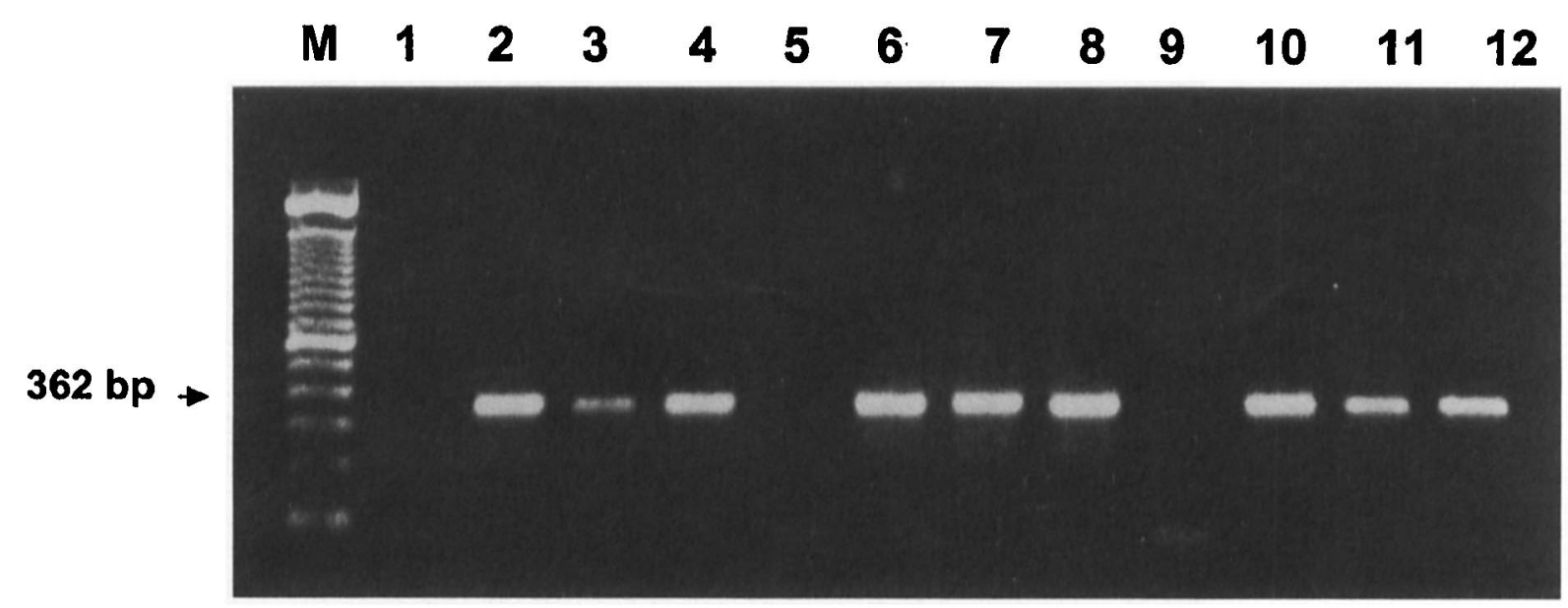

Fig. 2. Comparison of three DNA purification methods. Gel electrophoresis of amplification products after one-tube hemi-nested PCR (primers TM1, TM2 and TM3) for RH strain of T. gondii. Lane M, mol.-wt marker; 1-4, organic diluent method; 5-8, Boehringer-Mannheim method; 9-12, Macherey-Nagel method; 1, 5, 9, negative control (deionised water); 2, 6, 10, DNA from 100 parasites; 3, 7, 11, DNA from 10 parasites; 4, 8, 12, DNA from 100 parasites mixed with human leucocytes. 


\section{A: $\begin{array}{lllllllllllllllllll}1 & 2 & 3 & 4 & 5 & 6 & 7 & 8 & 9 & 10 & M & 11 & 12 & 13 & 14 & 15 & 16 & 17 & 18\end{array}$}

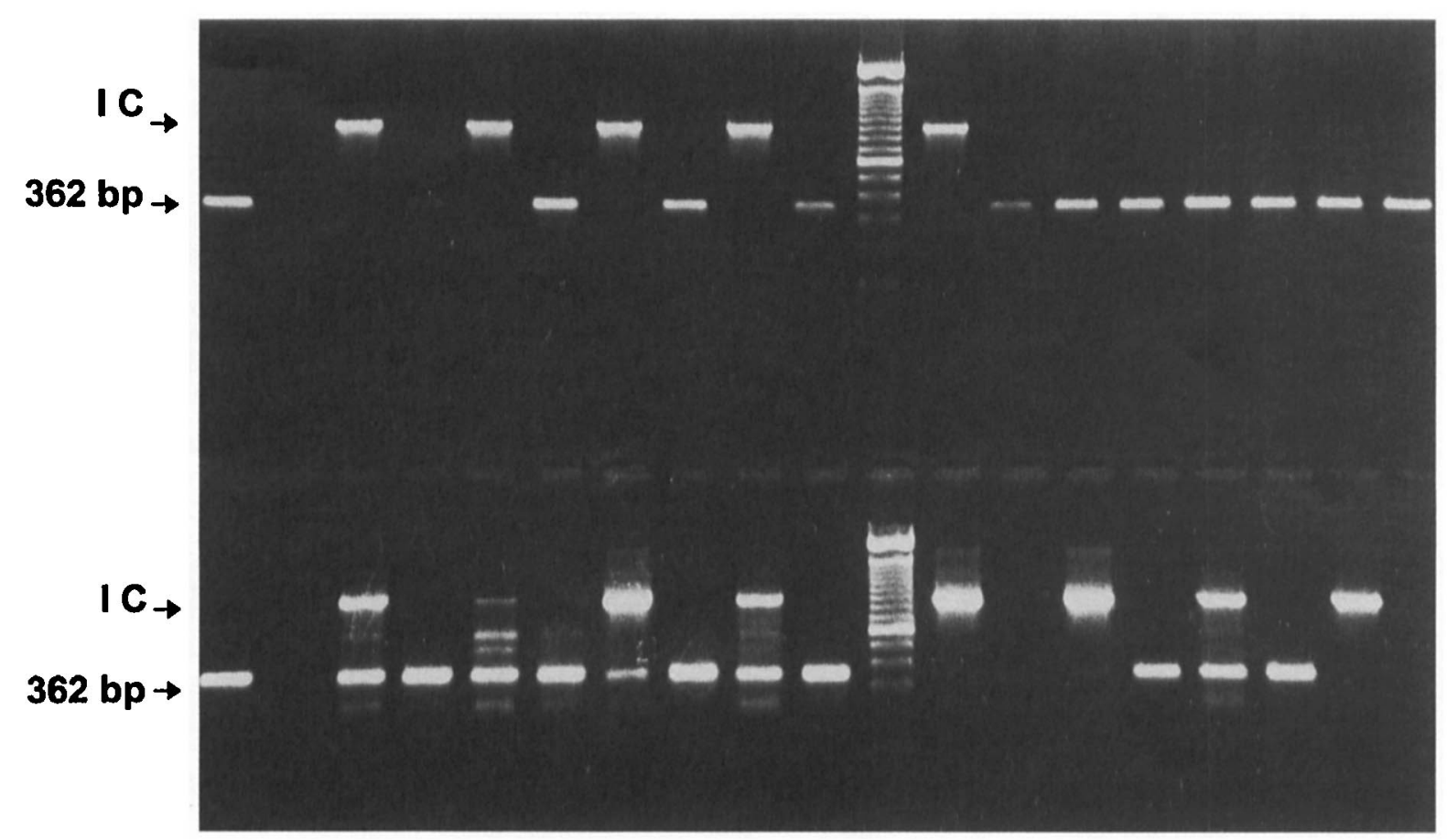

\section{B: $\quad \begin{array}{lllllllllllllllllll}1 & 2 & 3 & 4 & 5 & 6 & 7 & 8 & 9 & 10 & M & 11 & 12 & 13 & 14 & 15 & 16 & 17 & 18\end{array}$}

Fig. 3. Gel electrophoresis of amplification products after one-tube hemi-nested PCR for the clinical samples positive by cell culture. (A) Lane M, mol.-wt marker; 1, positive control (RH strain of $T$. gondii); 2, negative control (deionised water); 3 and 4, sample 1 with and without inhibition control (IC); 5 and 6, sample 2 with and without IC; 7 and 8, sample 3 with and without IC; 9 and 10, sample 4 with and without IC; 11 and 12, sample 5 with and without IC; 13 and 14, sample 6 with and without IC; 15 and 16, sample 7 with and without IC; 17 and 18, sample 8 with and without IC (bands of IC do not appear with samples 6 and 7, probably due to DNA competition). (B) Lane M, mol.-wt marker; 1, positive control (RH strain of T. gondii); 2, negative control (de-ionised water); $\mathbf{3}$ and 4, sample 9 with and without IC; 5 and 6, sample 10 with and without IC; 7 and 8, sample 11 with and without IC; 9 and 10, sample 12 with and without IC; 11 and 12, sample 13 with and without IC; 13 and 14, sample 14 with and without IC; 15 and 16, sample 15 with and without IC; 17 and 18, sample 16 with and without IC.

tested were stored in dry ice for $>24 \mathrm{~h}$ before processing for transportation. It is known that storage conditions affect the sensitivity of PCR [22]. Also, the uneven distribution of trophozoites in the samples cannot be ruled out.

In summary, these results suggest that preparation of clinical samples by proteinase $\mathrm{K}$ digestion in combination with a silica-based DNA purification method (such as the High Pure PCR Template Preparation Kit), followed by one-tube hemi-nested PCR may provide a rapid, sensitive and reliable method for detection of $T$. gondii DNA.

M. P-R is partially supported by a Prevni Fi de Residència 1997 from Hospital Clinic de Barcelona and a grant from the Fundación Máximo Soriaho (Barcelona). We thank Josep Costa and Jordi Vila for their assistance and advice.

\section{References}

1. Remington JS, McLeod R, Desmonts G. Toxoplasmosis. In: Remington JS, Klein JO (eds) Infectious diseases of the fetus and newborn infant, 4th edn. Philadelphia, WB Saunders. 1995: $140-267$.
2. Zangerle R, Allerberger F, Pohl P, Fritsch P, Dierich MP. High risk of developing toxoplasmic encephalitis in AIDS patients seropositive to Toxoplasma gondii. Med Microbiol Immunol 1991; 180: 59-66.

3. Derouin F, Devergie A, Auber P et al. Toxoplasmosis in bone marrow-transplant recipients: report of seven cases and review. Clin Infect Dis 1992; 15: 267-270.

4. Beaman MH, McCabe RE, Wong S-Y, Remington JS. Toxoplasma gondii. In: Mandell GL, Bennett JE, Dolin R (eds) Mandell, Douglas and Bennett's principles and practice of infectious diseases, 4th edn. New York, Churchill Livingstone. 1995: 2455-2475.

5. Speirs GE, Hakim M, Calne RY, Wreghitt TG. Relative risk of donor-transmitted Toxoplasma gondii infection in heart, liver and kidney transplant recipients. Clin Transplant 1988; 2: 257-260.

6. Luft BJ, Remington JS. Toxoplasmic encephalitis in AIDS. Clin Infect Dis 1992; 15: 211-222.

7. Derouin F, Thulliez P, Garin YJ. [Value and limitations of toxoplasmosis serology in HIV patients.] Pathol Biol 1991; 39: $255-259$.

8. Dannemann B, McCutchan JA, Israelski D et al. Treatment of toxoplasmic encephalitis in patients with AIDS. A randomized trial comparing pyrimetamine plus clindamycin to pyrimetamine plus sulfadiazine. Ann Intern Med 1992; 116: 33-43.

9. Raffi F, Aboulker JP, Michelet C et al. A prospective study of criteria for the diagnosis of toxoplasmic encephalitis in 186 AIDS patients. AIDS 1997; 11: 177-184.

10. Grover CM, Thulliez P, Remington JS, Boothroyd JC. Rapid prenatal diagnosis of congenital Toxoplasma infection by using polymerase chain reaction and amniotic fluid. $J$ Clin Microbiol 1990; 28: 2297-2301. 
11. Khalifa KES, Roth A, Roth B, Arasteh KN, Janitschke K. Value of PCR for evaluating occurrence of parasitemia in immunocompromised patients with cerebral and extracerebral toxoplasmosis. $J$ Clin Microbiol 1994; 32: 2813-2819.

12. Roth A, Roth B, Hoffken G, Steuber S, Khalifa KI, Janitschke $K$. Application of the polymerase chain reaction in the diagnosis of pulmonary toxoplasmosis in immunocompromised patients. Eur J Clin Microbiol Infect Dis 1992; 11: 11771181.

13. Loparev VN, Cartas MA, Monken CE, Velpandi A, Srinivasan A. An efficient and simple method of DNA extraction from whole blood and cell lines to identify infectious agents. $J$ Virol Methods 1991; 34: 105-112.

14. Burg JL, Grover CM, Pouletty P, Boothroyd JC. Direct and sensitive detection of a pathogenic protozoan, Toxoplasma gondii, by polymerase chain reaction. J Clin Microbiol 1989; 27: $1787-1792$.

15. Derouin F, Mazeron MC, Garin YJF. Comparative study of tissue culture and mouse inoculation methods for demonstration of Toxoplasma gondii. J Clin Microbiol 1987; 25: 15971600.

16. Verhosftede C, Reniers S, Colebunders R, van Wanzeele F, Plum J. Polymerase chain reaction in the diagnosis of Toxoplasma encephalitis. AIDS 1993; 7: 1539-1540.
17. Novati R, Castagna A, Morsica G et al. Polymerase chain reaction for Toxoplasma gondii DNA in the cerebrospinal fluid of AIDS patients with focal brain lesions. AIDS. 1994; 8: 1691-1694.

18. Brisson-Noel A, Aznar C, Chureau C et al. Diagnosis of tuberculosis by DNA amplification in clinical practice evaluation. Lancet 1991; 338: 364-366.

19. Gross U, Roggenkamp A, Janitschke K, Heesemann J. Improved sensitivity of the polymerase chain reaction for detection of Toxoplasma gondii in biological and human clinical specimens. Eur J Clin Microbiol Infect Dis 1992; 11: $33-39$

20. Lamoril J, Molina J-M, de Gouvello A et al. Detection by PCR of Toxoplasma gondii in blood in the diagnosis of cerebral toxoplasmosis in patients with AIDS. $J$ Clin Pathol 1996; 49: 89-92.

21. Guy EC, Pelloux H, Lappalainen $\mathbf{M}$ et al. Interlaboratory comparison of polymerase chain reaction for detection of Toxoplasma gondii DNA added to samples of amniotic fluid. Eur J Clin Microbiol Infect Dis 1996; 15: 836-839.

22. James GS, Sintchenko VG, Dickeson DJ, Gilbert GL. Comparison of cell culture, mouse inoculation, and PCR for detection of Toxoplasma gondii: effects of storage conditions on sensitivity. J Clin Microbiol 1996; 34: 1572-1575. 